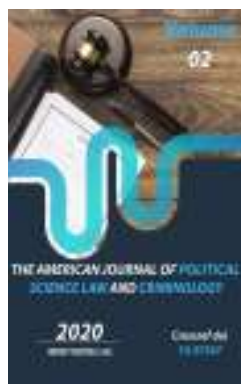

\title{
Entrepreneurship And Its Legal Bases
}

\author{
Berdikulov Mashrab Alikulovich \\ Head Of «Business Management» Educational Department, Yeoju Technical Institute In \\ Tashkent, Independent Researcher Of Tashkent State University Of Law, Uzbekistan
}

Journal Website: http://usajournalshub.c om/index,php/tajpslc

Copyright: Original content from this work may be used under the terms of the creative commons attributes 4.o licence.

\section{ABSTRACT}

In this article, the author makes an analytical approach of business entities activities and its legal bases in the Republic of Uzbekistan and abroad. In particular, the role of business entities in the economy of the country, its share in the volume of gross domestic product (GDP) was analyzed in comparison with other foreign countries. Opinions were drafted on the legitimization of the activities of business entities, which led to the term "legitimacy" of various definitions and concepts of scientists. At the same time, the author has widely covered the role of Republic of Uzbekistan in the international rating of the World Bank "Doing Business" criteria and the reforms carried out in this area through the legalization of entrepreneurial activity of business entities. In the current period of the pandemic, measures implemented in Uzbekistan and a number of developed countries to support entrepreneurship and their activities were compared. Proceeding from the article, in the summary section, the author put forward some suggestions and recommendations on legislation in the field of legitimization of business activity.

\section{KEYWORDS}

Legitimation, business management, international ranking, gross domestic product, small business, private entrepreneurship, pandemic, state registration, public service, licensing, road map, global crisis, preference.

\section{INTRODUCTION}

Nowadays it is not secret that business activity, i.e. entrepreneurship plays a very essential role in the economy of any country. In recent years, a number of laws and bylaws on the 
organization and further liberalization of our economy on a completely new basis, improvement (legitimation) of its legal framework, modernization and diversification of production, well-thought-out programs have been adopted and are being consistently implemented and adopted.

Of course, the fundamental basis of economic reforms in Uzbekistan is aimed at further development of small business and private entrepreneurship, creating freedoms for them and making them the leading force in the economy. In the context of modernization of the economy, the development of small business and entrepreneurship has a significant impact on ensuring macroeconomic stability.
As the President of Uzbekistan Sh. Mirziyoyev noted, "This is the further development of private property and entrepreneurship and ensuring their effective protection $[1,2017]$.

By providing legal support to small businesses and private entrepreneurship, they have become a leading link in the economy today. The development of small business and private entrepreneurship in our country, their share in the country's gross national product is growing.

According to the State Statistics Committee of the Republic of Uzbekistan, over the past 10 years, the share of small business and private entrepreneurship in the country's GDP is more than $50 \%$. This shows how important business is in the economy.

\section{The share of small business and private entrepreneurship [2]} (in\% of total volume)

\begin{tabular}{|c|c|c|c|c|c|c|}
\hline Year & GDP & Industry & Construction & Employed & Export & Import \\
\hline 2000 & $31,0^{*}$ & $12,9^{*}$ & $38,4^{*}$ & $49,7^{*}$ & 10,2 & 22,8 \\
\hline 2001 & $33,8^{*}$ & $12,5^{*}$ & $40,4^{*}$ & $51,8^{*}$ & 09,3 & 26,7 \\
\hline 2002 & $34,6^{*}$ & $15,4^{*}$ & $42,0^{*}$ & $53,5^{*}$ & 07,5 & 24,9 \\
\hline 2003 & 35.0 & 10,8 & 39.9 & 56.7 & 07,3 & 33.7 \\
\hline 2009 & 50.1 & 17,9 & 42.4 & 73.9 & 14,6 & 42.5 \\
\hline 2010 & 52.5 & 26,6 & 52.5 & 74.3 & 13,7 & 35.8 \\
\hline 2011 & 54.0 & 28,6 & 67.6 & 75.1 & 18,8 & 34.3 \\
\hline 2012 & 54.6 & 29,7 & 70.0 & 75.6 & 14.0 & 38.6 \\
\hline 2013 & 55.8 & 33.0 & 70.6 & 76.7 & 26,2 & 42.4 \\
\hline 2014 & 56.1 & 36.8 & 69.5 & 77.6 & 27.0 & 45.4 \\
\hline 2015 & $62,9^{* *}$ & 40.6 & 66.7 & 77.9 & 27.0 & 44.5 \\
\hline 2016 & $64,9^{* *}$ & 45.3 & 66.9 & 78.2 & 26.0 & 46.8 \\
\hline 2017 & $63,6^{* *}$ & 41.2 & 64.8 & 78.0 & 22.0 & 53.6 \\
\hline
\end{tabular}


The American Journal of Political Science Law and Criminology

\begin{tabular}{|l|l|l|l|l|l|l|}
\hline 2018 & $59,4^{* *}$ & 37.4 & 73.2 & 76.3 & 27,2 & 56.2 \\
\hline
\end{tabular}

*) small and medium business

**) The data for 2015-2018 are presented taking into account the data that have been accurately included (revalued)

In 2019 alone, the country's GDP amounted to 511.8 trillion soums ( 57.9 billion US dollars at the Central Bank's exchange rate), of which the share of products produced by entrepreneurs amounted to 300.3 trillion soums[3]. In percentage terms, this figure can be seen to be 58.6 percent in 2019 .

If it is to be compared with foreign developed countries, one can say that Uzbekistan has a higher performance in this area than some developed countries. For example, in the Russian Federation, the share of entrepreneurship in GDP is very low (21\%) and the government needs to carry out special reforms to increase this figure by 1.5-2 times. And this figure is expected to reach at least $32.4 \%$ by 2024 [4, 2019]. However, we can see that this figure is $48 \%$ in South Korea, $53 \%$ in Germany and $51 \%$ in the UK.

\section{The share of small and medium enterprises in GDP}

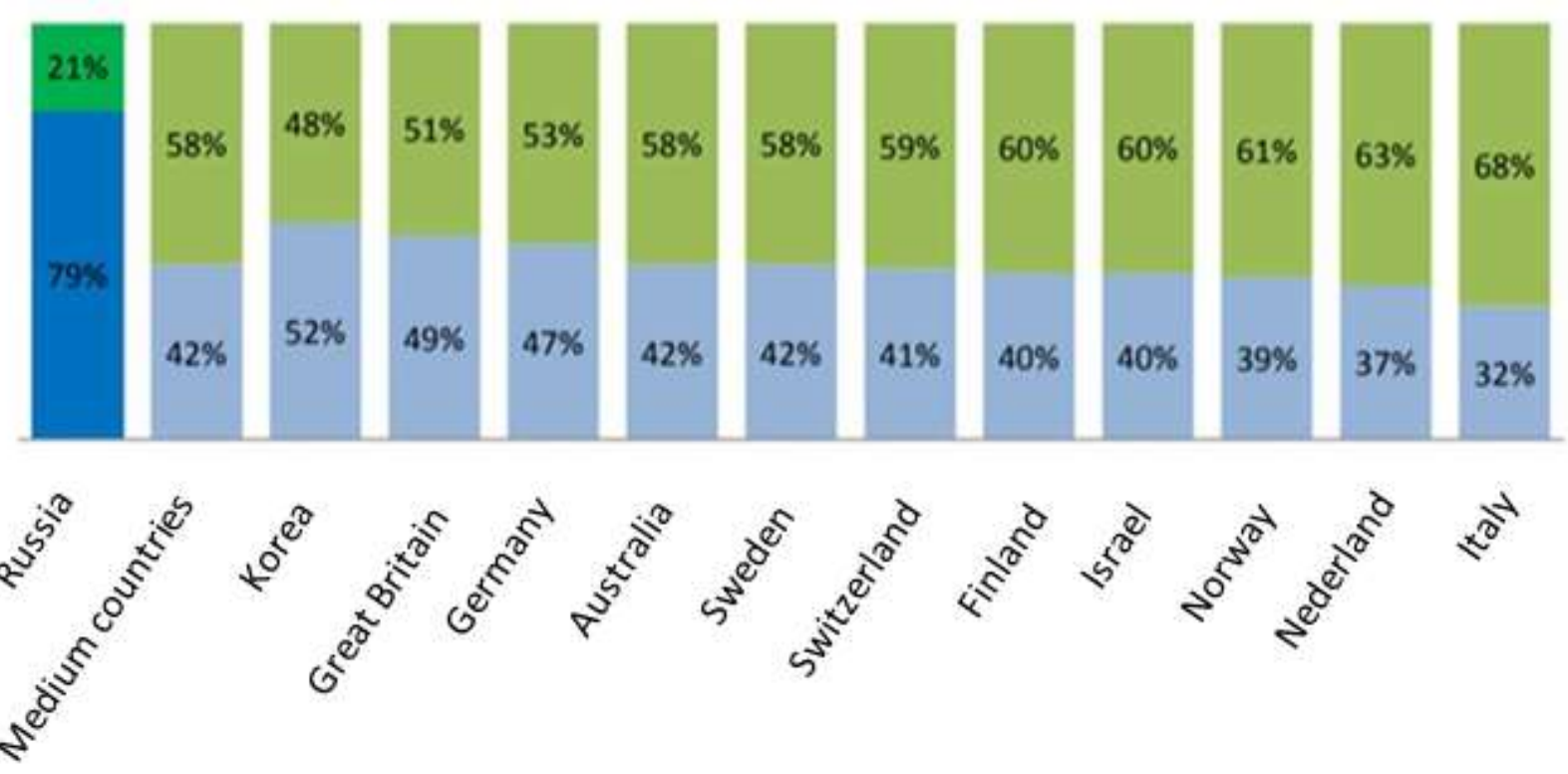

\section{The share of small and medium enterprises in the GDP of developed countries [5]}

While analyzing the share of small and mediumsized businesses in developed countries, the overall average is $58 \%$, it can be noted that the Republic of Uzbekistan is carrying out effective and targeted reforms in this area. Thus, it is necessary to emphasize once again the importance of entrepreneurship in the economy of any country. This means that the representatives of this business sector need a solid legal framework and legal protection in order to fully operate in the countries of the world, including Uzbekistan. In short, the 
legitimization of entrepreneurial activity is required.

\section{So what are the legal bases of entrepreneurship activity or in other words, what is legitimation and how does it play a role in business?}

Although the term legitimacy existed before, it came into widespread use in the field of law in the late 20th and early 21st centuries. In the field of law of our country, this term has been partially used in recent years. The word legitimation is derived from the Latin words "legitimus", "lex", "legis", which means law, legality, and legal, conformity with the law or the Constitution [6]. In English, there are the words "legitimation”, "legal”, "legacy”, which are defined as the act of making lawful [7]. Examples of the term "legitimacy" in Russian include "legitimization", "extension", "recognition of the right", ie "legitimization", "legalization" and "recognition of the right" [8].

In a classical piece on legitimation, Hybels recognized four main groups of organizational constituents: the state, the public, the media, and the financial community (1995). The state is important because governmental bodies not only control critical resources directly through the awarding of contracts and grants, but also indirectly influence the transfer of resources through regulation and legislation. The public is a critical actor because consumer groups and other 'public interest' groups affect legislation and regulation directly through lobbying and indirectly through influence on voters. The investment community legitimates both new and established organizations by determining the present values of firms based on rationalized appraisals intended to predict future returns on investment (collective assessments of future performance). Finally, the media not only reports illegitimate activities but also defines and evaluates grounds for the actions of entrepreneurs, managers, regulators, and investors (even though it has little direct control over the transfer of resources to organizations, it has considerable influence on the allocation decision of others).

While these four constituents provide different sources of legitimacy, three - state, public, and media - have overlapping norms and values by which they judge organizations, whereas the financial community uses at least partially distinct evaluation criteria [9, 1995].

Amitai Etzioni, an American sociologist and professor at George Washington University, sees legitimacy as a source of satisfaction from participation in enterprise in his book Entrepreneurship, Adaptation and Legitimation: A Macro-Behavioral Perspective. That is, it defines the belief that the decisions, documents, and actions of government leaders are just, moral virtues, and that they must be accepted in any situation $[10,1987]$.

It should be noted that the legitimization of $A$. Etzioni in his works is not only legal or legitimate, but also moral. An example of this is the statement of the International Independent Commission on Kosovo: "NATO's intervention in Kosovo was illegal, but legitimate" [11].

Well-known political scientist Dolf Sternberger (Dolf Sternberger 1907-1989), a professor at the University of Heidelberg in Germany, argued that legitimacy (legitimacy) is the basis of state power. This is done by the government as a consciousness because it has the right to be governed by the government and recognizes that the government has a right to it [12].

So today, legitimacy is one of the main conditions for doing business. One of the 
modern concepts of the term "legitimacy" was first interpreted in terms of jurisprudence in 2007 and defined in more detail as "... legalization, recognition or confirmation of the legality of the rights and powers of individuals and legal entities, as well as confirmation of the legality of relevant documents" [13, 2017]. The term "legitimacy" was first used in the doctrine of economic law by Professor V.S. Martemyanov, and the term was used in the "state registration of enterprises and individual entrepreneurs" [14, 1995]. Today, "legitimization" is one of the peculiarities of business law, the meaning of which is closely related to the state registration of business entities and licensing of certain types of economic activity, in the words of VV Laptev, an academician of the Russian Academy of Sciences $[15,2008]$.

Based on the above, we can give a legal definition of the term legitimacy as follows. Legitimation is the legal basis for the full legal implementation of the activities of business entities, the state's confirmation of the legitimacy of their rights and powers.

Therefore, the first major stage of legitimization is the state registration and registration of business entities that want to start their own business.

\section{Legitimation of entrepreneurship}

Nowadays, the term "legitimation" means "make legal, accept and approve the lawful rights and powers of natural and legal persons. And also confirm the legality by relevant documents".

In economic and business law sphere the term "legitimation" is mostly used for the state registration of companies and sole proprietors. And "legitimation" has become the main feature of the business law entities.
For some business law entities (such as, public educations and entrepreneurship unions, which do not have rights of legal entities) specific feature of legitimation of business entities is its law-determining character. Thus, in general by the term 'legitimation of business entities' it can be understood law-determining procedures, which provides legal character of business activity and lawful status of business entities. That's why, there should be noted the difference of legal consequences' between 'legitimation of business activities' and 'legitimation of business entities'.

Legitimation is the essence of the state registration of the business entities' activities and licensing some types of economic activities. It gives lawful basis for business entities and also provide legal opportunities to do some activities, which require special knowledge, technologic difficulty, risky for environment, essential for strategic interests of the state.

According to the Articles 24 and 44 of the Civil Code of Uzbekistan, entrepreneurship activity should follow state registration, which gives legal status to the business entity. Thus, it is recommended that the terms of 'legitimation of business entity' and 'legitimation of business entity's activity' should be differentiated. 'Legitimation of business entity' is the base for obtaining business status and gives opportunity to start business activity. 'Legitimation of business entity's activity' is interrelated with fulfilment of requirements, mentioned by the law to the already legitimated business entity

Extensive work is being done in the Republic of Uzbekistan in the field of business legitimization. In other words, there are many normative legal acts in our country related to the organization of business entities so that 
they can carry out their activities on a full legal basis.

Since the 1990s, on the eve of the collapse of the former Soviet Union and in the early years of independence, a number of decisions of the President and the Cabinet of Ministers have been made to legitimize the activities of business entities.

For example, the Regulation on the Procedure for State Registration of Enterprises in the Territory of the Uzbek SSR, approved by the then Resolution of the Council of Ministers of the Uzbek SSR No. 159 of June 12, 1991, and the Resolution of the Cabinet of Ministers No. 153 of 1994 Regulations on the procedure for state registration, registration and issuance of permits for business entities, approved by the Cabinet of Ministers of the Republic of Uzbekistan dated August 20, 2003 No. 357 and the President of the Republic of Uzbekistan No. PD-357 of 2006, PD-1529 of 2011 we can give an example of numerical solutions [16].

These normative legal acts, which have now lost their force, legitimized the legal basis for the organization of business in our country at that time, including the registration, registration, notification, and implementation in the prescribed manner.

In 2017, a completely new stage of legitimizing the activities of business entities began. The reason for this was the decision № PD-2646 "On improving the system of state registration and registration of business entities" adopted by the President of the Republic of Uzbekistan Sh. Mirziyoev on October 28, 2016. On the basis of this decision, a set of measures consisting of 32 points in 6 areas for radical improvement of the procedure for state registration and registration of business entities was approved $[17,2016]$.
In addition, on February 1, 2017, the President signed Resolution PQ-2750 "On additional measures to improve the mechanisms of providing public services to businesses". In accordance with this decision, the list of public services to be provided only to business entities through the Public Service Centers, which will be gradually introduced in 20182020, was approved. According to this list, 49 types of licensing activities and 19 types of licensing activities have been identified through the "single window" centers. In particular, the activities of audit organizations, stock exchanges, real estate, tourism, organization of lottery games will be licensed through these centers [18, 2017].

At the same time, on February 9, 2017, the Cabinet of Ministers of the Republic of Uzbekistan adopted Resolution № 66 on measures to implement the Resolution No. PD2646 of 28 October 2016. This decision approved the "Regulations on the procedure for state registration of business entities" [19, 2017].

These normative legal acts currently play a key role in legitimizing the activities of business entities in Uzbekistan.

These documents set out the legal basis for the registration, registration, permitting, licensing, re-registration, reorganization, implementation of activities, and liquidation of all legal entities in the country.

\section{World Bank “Doing Business" Rating}

As a result of the above-mentioned large-scale reforms in the field of business legitimization, the Republic of Uzbekistan is currently attracting many foreign investors. Naturally, these investments and the adopted normative legal acts will serve to further strengthen the position of our country in various international rankings. In particular, in recent years, 
Uzbekistan has taken a significant place among 190 countries in the international ranking of the World Bank "Doing Business".

Instead of information, it should be noted that the Doing Business rating represents the level of ease of doing small and medium business. Currently, a total of 11 indicators are assessed: business registration, obtaining construction permits, access to electricity, property registration, access to credit, protection of minority investors, and payment of taxes, cross-border trade, compliance mechanisms, bankruptcy, as well as labor market regulation and ease of installation. Doing Business is one of the most popular rankings describing the investment climate in the country, and in 2019 Uzbekistan was ranked 76th Compared to 2012, Uzbekistan rose by 78 positions [20].

It is gratifying that the most important stage in the legitimization of business activity in Uzbekistan is in the 12th place in this ranking in the business registration indicator. However, in this ranking, the activities of entrepreneurs in international trade (165th place), building permits / obtaining (134th place), elimination of non-payment (permits) (91st place), property registration (71st place), entrepreneurial activity We can see that the indicators of our country are not satisfactory in such indicators as obtaining a loan for (61st place) [21]. Therefore, there is still a need to work on the full legitimization of business activities in these areas on the basis of specific measures.

For this reason, many normative legal acts in this area have been adopted in our country and their implementation is being ensured. For example, the President of the Republic of Uzbekistan adopted Resolution No. PP-3852 of July 13, 2018 "On measures to further improves the rating of the Republic of Uzbekistan in the annual report of the World Bank and the International Finance Corporation "Doing
Business". The Financial Corporation's Doing Business report approved a Roadmap for Improving the Performance of the Republic of Uzbekistan [22, 2018]. In addition, the President of the Republic of Uzbekistan signed Resolution No. PP-4160 of February 5, 2019 "On additional measures to improve the rating of the Republic of Uzbekistan in the annual report" Doing Business "of the World Bank and International Finance Corporation". The annual report of the World Bank and the International Finance Corporation "Doing Business", developed in collaboration with the World Bank and other international financial institutions, approved a "Roadmap" to further improve the rating of the Republic of Uzbekistan. At the same time, this decision sets the target for improving the rating of the Republic of Uzbekistan "Doing Business - 2022" in the annual report of the World Bank and the International Finance Corporation "Doing Business", which envisages the country to reach 20th place by 2022 [23, 2019]. The "roadmaps" approved by the resolutions set out specific measures to be taken on the 10 indicators outlined in the annual "Doing Business" report and the competent authorities.

For example, the activities of entrepreneurs with the lowest indicators in the business ranking in international trade (165th place) In accordance with the Presidential Decree № PD-4160 of February 5, 2019 in the field of international trade - issuance of a certificate of origin as well as on the basis of the applicationdeclaration of the participant of foreign economic activity, within the period not exceeding one working day from the date of submission of the application by the Chamber of Commerce and Industry. This norm, of course, serves to enhance the position of our country on this indicator. 
At the same time, in his Petition to the Oliy Majlis in January 2020, President of Uzbekistan Shavkat Mirziyoev noted that all organizational and legal measures have been taken to make our country one of the top 50 countries in the World Bank's “Doing Business” ranking [24].

\section{Legitimization of entrepreneurship in 2020 (pandemic period)}

By March 2020, the ongoing reforms in our country to legitimize business activities have faced serious obstacles. It is all-known that the spread of coronavirus infection around the world, the need to restrict the movement of people and the need to shut down businesses, the sharp decline in production and consumption in countries with the largest economies are having negative consequences around the world. This has led to the disruption of global production chains and trade ties, falling commodity prices in world financial markets and deteriorating conditions.

Naturally, these factors also affect the economy of Uzbekistan, which is part of the global economic system, which in turn requires effective preventive measures to mitigate the negative effects of this situation.

In the fight against the spread of coronavirus infection and other global threats, there is a need to pay special attention to ensuring and maintaining macroeconomic stability, uninterrupted operation of sectors and industries of the economy, stimulating foreign economic activity.

In this regard, a number of normative legal acts were adopted in order to support business entities and their activities, to legitimize the activities of representatives of this sector during the pandemic.

In particular, the President of the Republic of Uzbekistan № PF-5969 [25, 2020] of March 19, 2020 "On priority measures to mitigate the negative impact of the coronavirus pandemic and the global crisis on the economy", April 3, 2020 "On the population, sectors and businesses during the coronavirus pandemic" PF-5978 [26, 2020] "On additional measures to support the population and businesses" and PF-5986 [27, 2020] "On additional measures to support the population and businesses during the coronavirus pandemic" dated April 27, 2020. Measures are being taken to expand social support and ensure the sustainable operation of various sectors of the economy.

On the basis of these decisions, an Anti-Crisis Fund worth 10 trillion soums was established to support the population and entrepreneurs.

Tour operators, travel agents and entities providing hotel services (accommodation services) in the field of tourism, JSC "Uzbekistan Airways" and its subsidiaries, JSC "Uzbekistan Airports" and SUE "Uzbek-Iran Navigation Center" from April 1 to December 31, 2020 exempted from paying property tax on individuals.

For individual entrepreneurs who were forced to suspend their activities during the quarantine period, the calculation of a fixed amount of personal income tax and social tax was suspended.

Interest-free deferral of the following taxes until December 31, 2020, notifying the tax authorities of micro-firms, small businesses and individual entrepreneurs whose activities have ceased and (or) revenues from the sale of goods (services) decreased by more than $50 \%$ compared to the average monthly amount in the first quarter of this year The right to pay in installments was granted:

- On turnover tax, property tax, land tax, water use tax without application to local state authorities - on the 
condition that they are paid in equal installments within 12 months;

- On social tax - on the condition that it is paid in equal shares later for 6 months.

- $\quad$ At the same time, until October 1, 2020, the State Fund for Entrepreneurship Support:

- Guarantee in the amount of not more than $75 \%$ of the loan amount, but not more than 10 billion soums, provided to businesses with a positive credit history, regardless of the number of projects, to replenish working capital;

- Compensation was provided to businesses to reimburse working capital in the national currency at an interest rate not exceeding 1.75 times the base rate of the Central Bank, while retaining its established amounts.

In case of overdue receivables of business entities in the reporting year not exceeding $10 \%$ of total exports, the exports of goods without collateral, as well as the repayment of overdue receivables on foreign trade operations in 2020 in exchange for technological equipment and raw materials, one-time import operations were allowed. In addition, a total of 18 trillion soums were extended to 87,000 business entities, and more than 5 trillion soums to about 2 million citizens.

In April 2020 alone, 250,000 entrepreneurs and enterprises, 83,000 farms were delayed in paying taxes and other payments totaling 400 billion soums. More than 11,000 entrepreneurs using state property have been exempted from paying rent.

The video conference chaired by the President of the Republic of Uzbekistan Shavkat Mirziyoev on 13 May also outlined the following measures to be taken for business entities and their activities.
First, the social tax rate for small businesses and farms will be reduced from 12 percent to 1 percent in May-July. As a result, more than 260,000 enterprises and farms will be able to save a total of 650 billion soums and use them as capital and working capital.

Second, small business representatives, sole proprietors will be exempt from land and property taxes for the next three months. As a result, more than 50,000 entrepreneurs will save 300 billion soums and their working capital will increase.

Also, according to the previous decision, in April-May, more than 1,000 entrepreneurs will be delayed payments of 80 billion soums on land and property taxes and fines.

Third, entrepreneurs will be allowed to pay customs duties with a delay of up to 120 days. This will allow them to save a total of 540 billion soums and direct these funds to the development of their business.

In addition, the amount of compensation for loans to entrepreneurs up to 500 billion soums (previously up to 10 billion soums) to replenish working capital will be increased from $5 \%$ to $10 \%$.

In addition, in order to increase domestic demand for the products of local enterprises and thereby support them, government agencies will be given the right to make purchases in the III-IV quarters in the II quarter.

In general, the President noted that more than 2 trillion soums will be allocated from the budget to further support the economy, entrepreneurs and their activities, as well as citizens [28].

It can be noted that, the main efforts by government to legitimate business activities are: 
- Entrepreneurs engaged in tourism and hotel business are exempt from paying land and property taxes until the end of the current year. Social tax rate for them is reduced from the current 12 to 1 percent.

- The calculation of a fixed amount of personal income tax and social tax for individual entrepreneurs who have been forced to suspend their activities for the period of quarantine is suspended.

- Small businesses, the revenue of which has decreased by 50 percent compared to the previous month, are granted the right to defer payment of turnover taxes, land tax, property tax, social and water taxes until October 1 this year.

- A new system was been introduced to create decent conditions for self-employed citizens. Thus, hairdressers, shoemakers, bakers, blacksmiths, carpenters, tailors, taxi drivers, photographers, translators, designers, programmers - the selfemployed representatives of more than 60 professions will be exempt from income tax. To take advantage of this benefit, it will be enough to notify the tax authorities by phone. Based on international best practices, a mobile application will be developed for registration and accounting of self-employed citizens.

Naturally, such privileges and preferences provided by the state to business entities create a great basis for the rapid recovery of the country's economy, the restoration of living standards and re-employment in the current difficult conditions.

In the context of the pandemic, as it was mentioned above, Uzbekistan provided and still providing a number of preferences and benefits to businesses in order to restore the economy to its former state, stabilize the living standards of the population and keep them busy.

\section{CONCLUSION}

As a conclusion, it can be mentioned that in today's market economy, the business sector is the most important, whether at the international level or at the level of any country. Entrepreneurs, whose activities greatly contribute to the coordination of living conditions of peoples, employment, a stable source of income, the integrated development of the economy. Therefore, the creation of a legal framework for the legitimization of entrepreneurial activity, including the establishment of business entities, state registration, registration, licensing and implementation of activities is of great importance for the economy of our country. To this end, it is proposed to develop a single normative legal document covering the process from the establishment to liquidation of all types of business entities. The pandemic conditions have shown that no country is fully prepared for such force majeure in advance. It is recommended to include in this new normative legal document norms on the regulation of their activities during force majeure and quarantine. At the same time, it is proposed to introduce the term "legitimization" or "legitimization" of entrepreneurship as a legal term.

\section{REFERENCES}

1. Decree of the President of the Republic of Uzbekistan dated February 7, 2017 "On the Strategy for further development of the Republic of Uzbekistan". Lex.uz

2. Official website of the State Statistics Committee of the Republic of Uzbekistan https://stat.uz/uz/180-ofytsyalnaiastatystyka-uz/6576-small-business-andentrepreneurship

3. web.stat.uz/open_data/ru/makroko'rsatki chlar1_ru.pdf 
4. Rosstat for the first time revealed the share of small and medium-sized businesses in the economy. https://www.rbc.ru/economics/05/02/2019/ 5c5948c59a794758389cfdf7

5. Small and Medium Business Sector: Russia and the World -Institute for Growth Economics Stolypina P.A. http://stolypin.institute/novosti/sektormalogo-i-srednego-predprinimatelstvarossiya-i-mir/

6. https://www.politicalsciencenotes.com/art icles/legitimacy-of-political-systemconceptual-explanation-of-legitimacy/554

7. http://www.yougowords.com/browse/legi timation

8. Dictionaries and Encyclopedias on the Academician https://dic.academic.ru/dic.nsf/ushakov/84 8702

9. Hybels, R.C. 1995. On legitimacy, legitimation, and organizations: A critical review and integrative theoretical model. Academy of Management Journal (00014273): 241-241.

10. Etzioni, Amitai, Entrepreneurship, Adaptation and Legitimation: A MacroBehavioral Perspective (April 1986). Journal of Economic Behavior and Organization, Vol. 8, pp. 175-189, 1987. Available at SSRN:

https://ssrn.com/abstract=1437032, https://www.politicalsciencenotes.com/articles/legitimacy-of-politicalsystem-conceptual-explanation-oflegitimacy/554.

11. http://pu.virmk.ru/arhiv/2012/02/EtzioniPetrosyan.htm - Amitai Etzioni Communitarianism as the key to world legitimacy III Amitai Etzioni - On Communitarian and Global Sources of Legitimacy.

12. https://peoplepill.com/people/dolfsternberger/, Legitimacy of Political
System: Conceptual Explanation of Legitimacy. https://www.politicalsciencenotes.com

13. Raizberg B.A., Lozovsky L. Sh., Starodubtseva Ye. B. Modern economic dictionary. 5th ed., Revised and added. Moscow. INFRA-M, 2007.

14. Martemyanov V.S. Commercial law. T. I: General provisions: Lecture course. Moscow. 1994. - p. 55.

15. Laptev V.V. Contemporary problems of entrepreneurial (economic) law // V.V. Laptev. Entrepreneurial (economic) law. Selected Works. Ekaterinburg, 2008. - p. 221.

16. Lex.uz - National Database of Legislation of the Republic of Uzbekistan.

17. On Legislation of the Republic of Uzbekistan, 2016, No. 45, Article 522, https://lex.uz/docs/3063485

18. On Legislation of the Republic of Uzbekistan, 2017, No. 5, Article 61, https://lex.uz/docs/3103829

19. On Legislation of the Republic of Uzbekistan, 2017, No. 7, Article 89, https://lex.uz/docs/3111347

20. http://uz.infocom.uz/?s=doing+business

21. https://www.norma.uz/nashi_obzori/uzbe kistan_zanyal_76e_mesto_v_reytinge_doing business.

22. https://lex.uz/docs/3822465 - National Database of Legislation, 14.07.2018, 19.03.2020, No. 06/20/5968/0331.

23. https://lex.uz/docs/4190714\#4191952 National Database of Legislation, 06.02.2019, No. 07/19/4160/2578; 08.03.2019, 06/19/5687/2723.

24. Petition of the President of the Republic of Uzbekistan Shavkat Mirziyoev to the Oliy Majlis http://uza.uz/en/polits /

25. https://lex.uz/docs/4770761 - National Database of Legislation, 20.03.2020, No. 06/20/5969/0341) 
26. https://lex.uz/docs/4780475 - National Database of Legislation, 03.04.2020, No. 06/20/5978/0393

27. https://lex.uz/docs/4800005 - National Database of Legislation, April 28, 2020, No. 07/20/5986/0510)

28. Shavkat Mirziyoev: We will continue to ease the quarantine requirements while holding the reins of the epidemiological situation.

https://president.uz/uz/lists/view/3569

Official website of the President of the Republic of Uzbekistan. 